Article

\title{
Evaluation of the Effectiveness of Border Policies in Dehong Prefecture of Yunnan, China
}

\author{
Qianlong Bie ${ }^{1}$, Cansong $\mathrm{Li}^{1,2}$ and Shangyi Zhou ${ }^{1, *}$ \\ 1 School of Geography, Beijing Normal University, Beijing 100875, China; \\ E-Mails: bieqianlong@mail.bnu.edu.cn (Q.B.); cansongli@mail.bnu.edu.cn (C.L.) \\ 2 School of Economic and Management, Yunnan Normal University, Kunming 650500, China \\ * Author to whom correspondence should be addressed; E-Mail: shangyizhou@bnu.edu.cn; \\ Tel.: +86-10-6224-7385.
}

Received: 26 May 2014; in revised form: 30 July 2014 / Accepted: 1 August 2014 /

Published: 13 August 2014

\begin{abstract}
With the process of globalization, many political geographers and research institutions have begun to focus on borders and border areas. Faced with the current debate on the border policies, this paper reviews the former research relating to border studies and provides an evaluation of China's border policies. The literatures on border effects reveal that national boundaries have a significant impact on the economic, social and cultural relations of both border regions. Because of these effects, each country has to adjust its border policies in different periods. In this paper, a perspective is provided for evaluating the effectiveness of China's border policy based on the Kaldor-Hicks analysis method. We investigated the border policies in Dehong Autonomous Prefecture in Yunnan province of China from 1949 to 2012, and evaluated the effectiveness of the border policy using the Kaldor-Hicks method. The conclusions include: first, the Kaldor-Hicks method can be seen as effective method to evaluate the effectiveness of China's border policies. Second, based on the Kaldor-Hicks method, we observe the overall effects of the adjustments made to the border policies in Dehong Prefecture were positive. However, sometimes the border trade policy is good for the country as a whole, but not necessarily for Dehong Prefecture. For the sake of the whole country, adjustments in border trade policy need to be compensated by financial transfer payments. In addition, the combined effects of the cross-border marriages policy are not immediately obvious.
\end{abstract}


Keywords: border; policy evaluation; Kaldor-Hicks standard; cross-border ethnic areas; Yunnan

\section{Introduction}

There are some controversies surrounding border policy studies related to China, which suggest that researchers provide different some perspectives and views [1-3]. Therefore, it is increasingly important to evaluate the effects of a border policy from a wide range of perspectives. Some scholars have focused on the significance of borders and analyzed the border policy from the perspective of the national economy, national development, security and equality [4,5]. Especially with regard to the effects of border policies, there are many potential research topics and evaluation methods [6-8]. The effectiveness of border policies is primarily reflected in the consistency of the achievement level of the policy itself and the actual target of the policy, as well as the impacts on the economic and social life of border regions. The paper will discuss whether the border policies are effective and how to interpret the effect or impact of the policies. We consider it essential to make periodic reviews of the effects of the border policies. Because border policy is a very complex multi-objective balancing process, national scholars have put forward their own views [9-11]. It is often thought that border policies do not achieve the stated targets, especially regarding the management of migrants, commodities, goods, services and information within the border areas. Most existing literature does not provide a thorough research on China's border policy theories, or an understanding of cross-border ethnic areas and groups within China.

Based on a detailed study of border policy effects, we propose to integrate these important results into existing research issues [12-15]. The critical issue is to define different and special border management objectives such as national security [16], economic development [17], social justice [18], ecological protection and cultural prosperity [19]. These goals can be further boiled down to several broader objectives, such as to protect legitimate trade, tourism, services, commercial activities; to prevent illegal trade, drug trafficking and smuggling; and to fight against terrorism and other criminal activities [20,21]. Border policy is seen as a double-edged sword, having both advantages and disadvantages. Therefore, we need to evaluate whether the advantages outweigh the disadvantages; the Kaldor-Hicks method provides us with a useful guideline for evaluation. With changes in China's relations with neighboring countries, timely adjustments need to be made to China's border policies. In this study, we mainly evaluate the effects of border policies in China from 1949 to 2012. The border policy has two basic objectives, the first is to limit people, goods and the flow of information within the border areas for national security reasons; second is to try and to reduce the development gap between border areas and inland regions. China has developed and implemented a series of preferential policies to support economic development in border areas and to strengthen the national identity of residents living there. 


\section{An Overview of Border Policy in Yunnan Province}

\subsection{Study Area}

Yunnan Dehong Autonomous Prefecture border shares a boundary with Myanmar (see Figure 1). The Prefecture boundary accounts for $2.2 \%$ of the national land boundary length, and $25 \%$ of the China-Burma border line. This border has been peaceful since 1949, which is mostly due to the policy of handling boundary issues that arose between the two countries.

Dehong serves as an important transport link between China and Myanmar. The highway connects Lashio, Mandalay, Bhamo, Myitkyina and other important towns in Myanmar. Although Dehong Prefecture is not in the core of China's foreign trade today, historically, it was a fort on the ancient Southern Silk Road. With the Burma and Stilwell Roads passing through the area during World War II, it assumed an important role of wartime transport. The oil and gas pipeline recently constructed by China in Burma also passes through this area.

Figure 1. The location of Dehong Dai and Jingpo Autonomous Prefecture. (a) The location of Yunnan Province in China; (b) The location of Dehong Prefecture in Yunnan Province; (c) The location map of Dehong Prefecture.

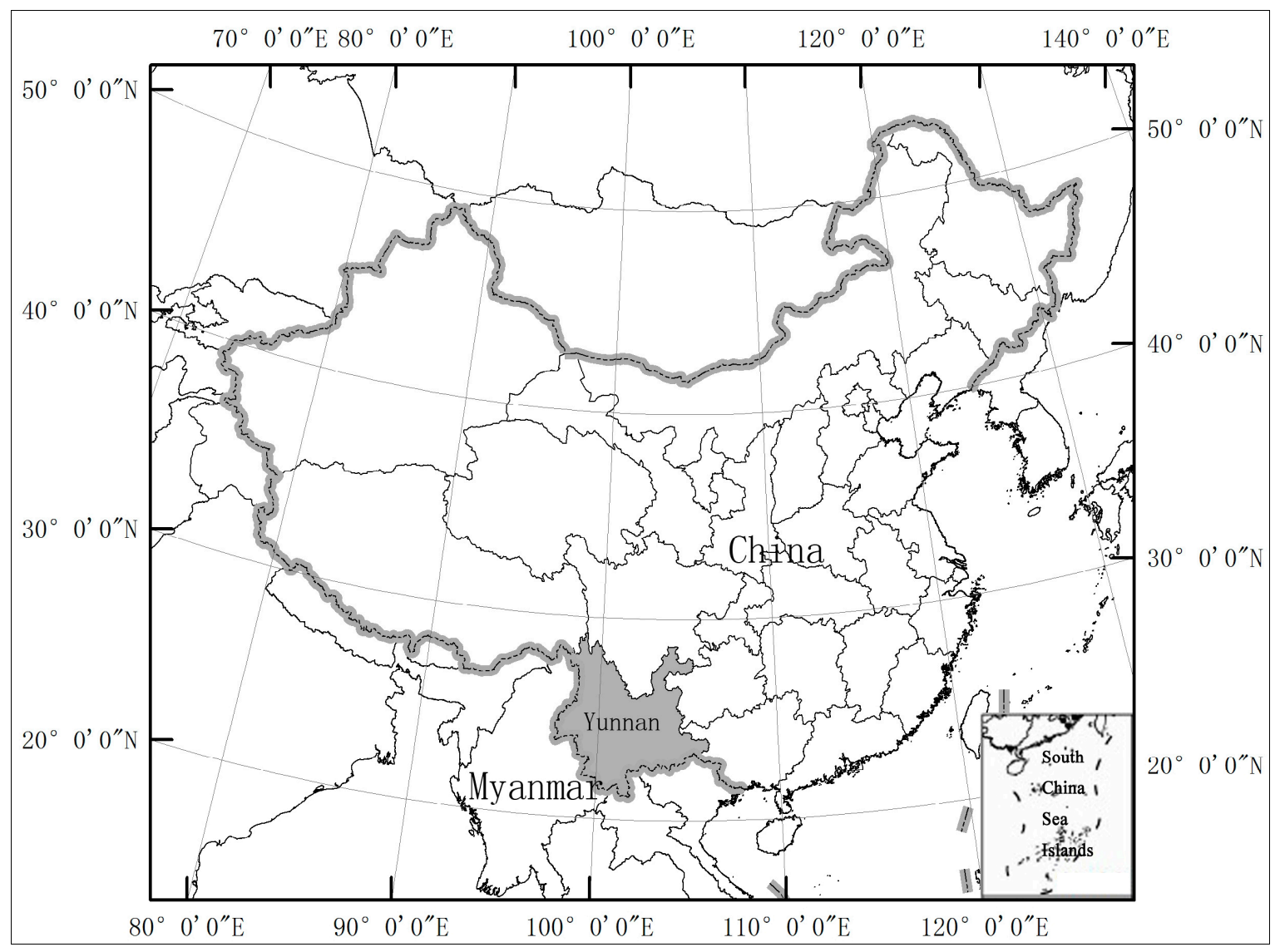

(a) 
Figure 1. Cont.

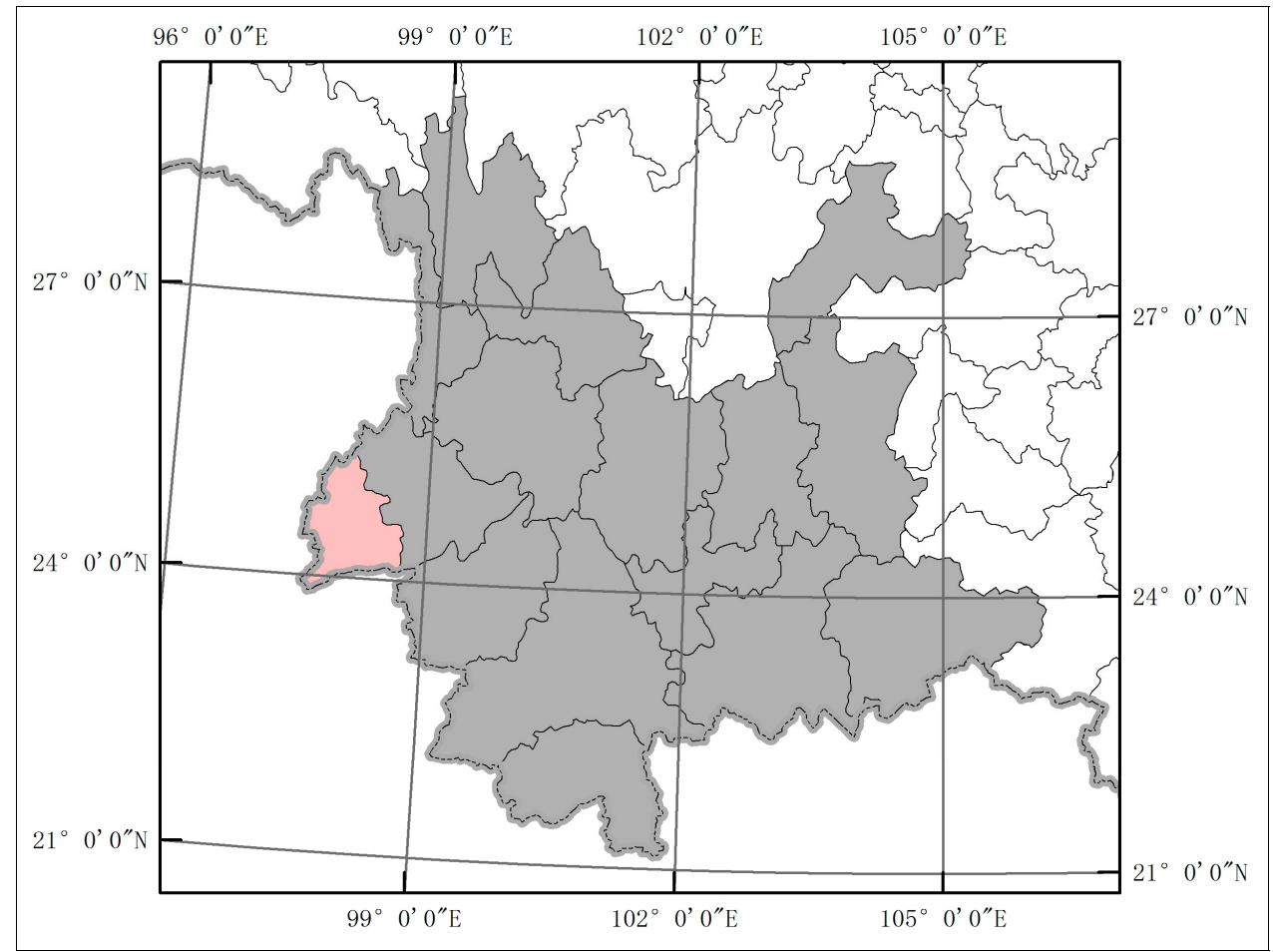

(b)

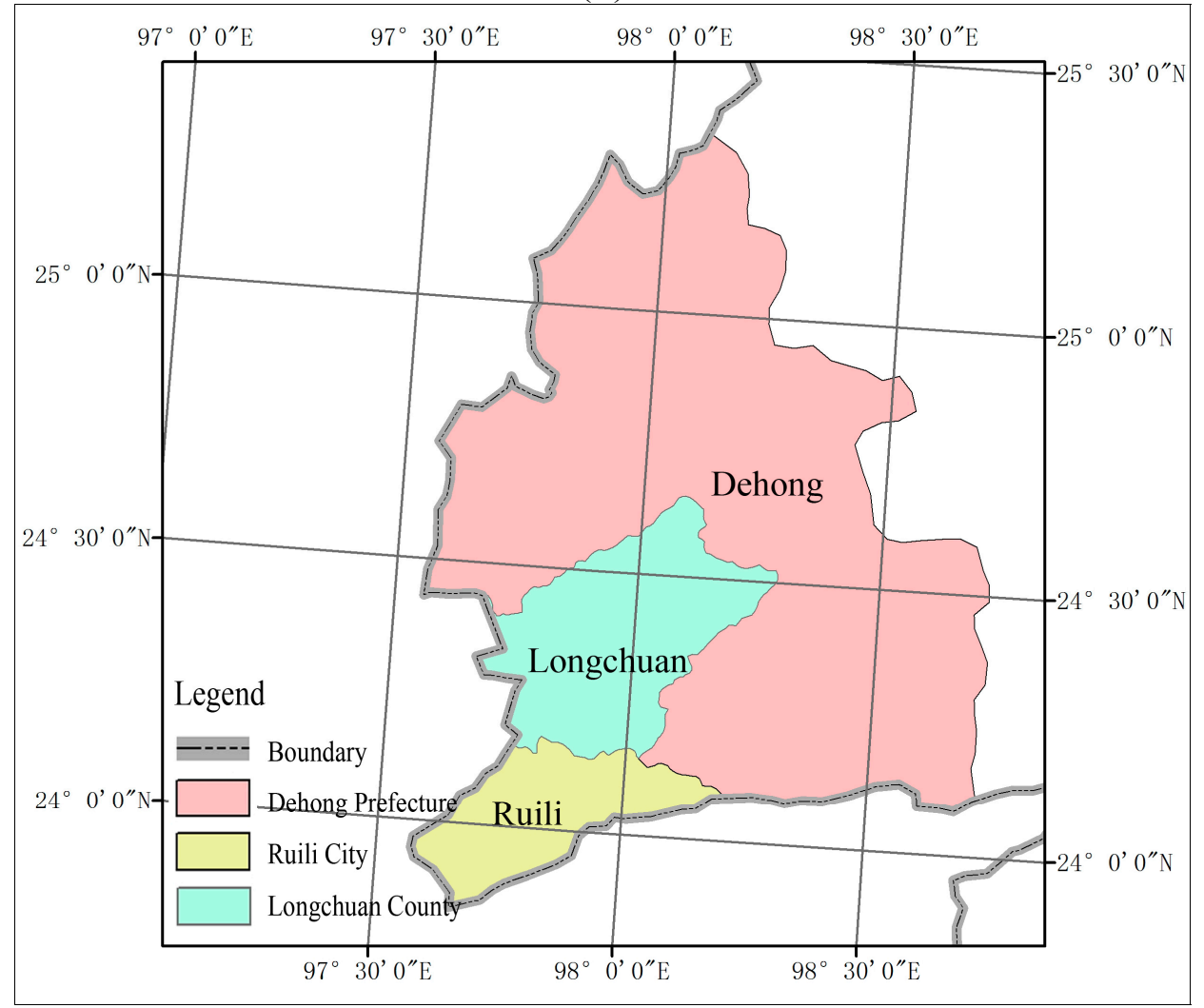

(c)

Dehong is associated with an important cross-border ethnic area; people on both sides of the border communicate closely. $49.7 \%$ of the population in Dehong belong to an ethnic minority, including the Dai, Jingpo, Achang, Déang, Lisu and other cross-border ethnic groups. Although Dehong is in a mountainous region, there is no insurmountable natural barrier between China and Myanmar. After the 
founding of People's Republic of China, the border was defined. The relationships among ethnic minorities in the border areas between Dehong and Myanmar are cordial; and it is one of China's most friendly and peaceful border regions. However, because there are languages and kinship ties between people on both sides, and people can move easily, illegal immigration, smuggling, drug trafficking, cross-border crime exist. These pose major problems in border management.

\subsection{Practice of Border Management Policy and Changes in Yunnan}

China's border policies include both general and specific policies. The basic policies refer to safety management, public security management and other administrative work developed by the country in border areas. The specific policies refer to the policies and regulations developed according to the specific conditions of different border regions. These generally involve three types of policies: people in transit, trade and border area development. The entry and exit of people involve the Ministry of Public Security and the Ministry of Foreign Affairs; transnational marriages involve the Ministry of Civil Affairs, and international trade involves the Commerce Department, Customs and the Port Administration. We next discuss the border policies during two periods.

The first period was from 1949 to 1978. Although this stage is lengthy, China's connection with the outside world was a relatively closed one. After the founding of the People's Republic of China, the country set up border management agencies, established organizational forms and tasks, and formulated the basic system and policies of border management. In 1960 the Prime Minister of Myanmar, Ne Win visited China, and signed The Agreement on Border Issues between the Government of the People's Republic of China and the Government of the Union of Myanmar on 28 January. In the same year, the Prime Minister U Nu and Chief of Staff Ne Win visited China and signed the Border Treaty between the People's Republic of China and the Union of Myanmar on 1 October. Although signing the treaty could not prevent some of the armed conflict on the border itself, there were also some negative effects. During this period, the major purpose of the border policy between China and Myanmar was basically to maintain the regular operations, entry-exit orderliness, an emergency response for refugees and cross-border management. However, during this period the management of personal enter-exit still remained very weak. Many Chinese could enter northern Burma through this route, and even reach other parts of the world.

The second period was after 1978, when China entered a new era of the reform and opened up to the world with the development of the economy at the center. China continued to improve relations with neighboring countries, and constantly adjusted policies in border areas at national and Dehong levels. The Law on Regional Ethnic Autonomy issued by the State in 1984 specifically related to border policies. The main aspects of these policies involve management of population flows, cross-border marriages and border trade. During this period, economic targets were the main objective of border management. For example, the State Council approved Ruili, Wanding and Hekou as Border Economic Cooperation zones in 1992. In May 2011, with the support by the State Council, Malipo (Tianbao), Gengma (Mengding), Tengchong (Houqiao), Menglian (MengAh) and Lushui (Pianma) Border Economic Cooperation Zones were constructed in Yunnan. In 1996, the Yunnan provincial government issued Implementation Measures for Cross-Border Trade and Economic Management in Yunnan, in which the provisions for cross-border trade promoted local economic development. 
In 2004, the Standing Committee of Yunnan Provincial People's Congress approved the repeal of the Regulations on Border Trade and Economic Management in Dehong Autonomous Prefecture in Yunnan Province (Trial), because it had conflicts with The Regulations on Border Economic and Trade Management of Yunnan Province. Thus, we can see that global interests and local interests were part of border policies.

\subsection{Three Crucial Policies Implemented in Dehong}

The first point relates to the policies for the management of people entering and exiting the countries. There are two types of people entering and exiting: residents and non-residents living along the border area. The management of three sections of the China-Burma border policy changed from military guard into administrative management since 1986. In accordance with The Entry-Exit Administration Law of People's Republic of China, "foreigners not holding official passports and border passes are prohibited from entering and exiting the border areas of China from Sino-Burma border. If a Chinese border resident wants to enter or leave the country, he should register with the police station at his registered permanent address, and enter from the designated port”. Especially since 1990, the number of people entering China along the Dehong border has surged. Currently 6 million people enter or leave China from Dehong annually [22]. Some Chinese citizens participated in gambling in Myanmar resulting in some major criminal cases. On 2 November 2005, the business of operating the long-distance certificate application for border tourism from different locations in Dehong and Xishuangbanna was officially stopped, which resulted in significant economic losses for Dehong. When one-day tours to the China-Burma border first opened, the number of tourists from Dehong reached 290,000. After the policy of certificate application for border tourism from within different locations was abolished, the occupancy of hundreds of top class hotels was less than half than before and the business of travel agencies was down nearly 70\%. After consultation with the Governments of Myanmar and Vietnam, gambling establishments on the Myanmar border side were demolished and a new travel management approach was implemented. On 27 November 2013, the Exit-Entry Administration of Yunnan Public Security Department was officially approved by the Ministry of Public Security and National Tourism Administration and the Wenshan, Honghe, Xishuangbanna, Baoshan and Dehong prefectures were allowed to handle certificate application for border traveling from different locations. In addition, on 31 December 2013 the People's Government of Dehong Prefecture promulgated the Interim Measures for the Management of Workers from Outside of Dehong, which requires that in order to work in Dehong, an outside border resident should hold a health certificate for international travel, a registration certificate for foreign workers, a visa, a residence permit and a temporary residence permit for people living outside the boundary of Yunnan.

The second priority related to transnational marriage management policies. As an important part in cross-border exchanges, cross-border marriages have an important impact on social security and stability in border region. On 17 February 1995, the Ministry of Civil Affairs issued regulations that marriage between border resident of the adjoining country and in China must comply with Chinese regulations on marriage, must hold valid travel and identity documents, and must have proof of consent to marriage and a health certificate. In addition, they must apply for a marriage certificate in the Civil Affairs Department of the provincial capital. However, for various reasons, the cross-border 
marriage population who register their marriages at the provincial capital is small. On 9 September 2010 the Public Security Bureau of Dehong Prefecture and the Bureau of Civil Affairs jointly issued Regulations on Management of Cross-border Marriage Registration Certificate in Dehong (Trial), aiming to change the current state of low registration rate of cross-border marriages in Dehong. These can provide important information for the management of foreign affairs, family planning, labor, health, education and other sectors. Dehong was the first area in China to issue such regulations. According to the information from the Public Security Bureau of Dehong, as of 30 June 2010, the number of Chinese citizens who married with foreigners (primarily Burmese) was 8140, most were de facto marriages, that is, they have no marriage certificates.

There is still a more powerful reason to focus on cross-border trade policies. Since Myanmar and China signed a cross-border trade agreement in 1988, the governments at all levels of Yunnan Province developed appropriate incentive policies to actively develop border trade. Since 1991, the relevant government departments have issued a series of preferential policies to support the opening up and development of border trade in border provinces, especially the port or gateway area which enjoys tax breaks. Beginning in April 1996, and in line with the international environment of China's foreign trade, relevant border policies were adjusted (No. 2 document of the State Council), and 162 kinds of duty-free concessions of goods were canceled. From 1996 to 1998 import tariffs and import taxes were halved at the statutory rate, and border trade was included in general trade management regulations. When viewed at the national level, these measures regulated the border trade between China and other countries, but constrained the border trade in Dehong [23]. Subsequently, the State Council issued new provisions for a border tax policy which was implemented until the introduction of a new border tax policy in 2012. The border trade and foreign investment policies stimulated rapid economic development in Yunnan Province. Opening land crossings is an important measure for promoting border trade. The boundary between Yunnan and Myanmar is longer than that Vietnam and Laos. These are also more entry posts with Myanmar than that with Vietnam and Laos [24].

In summary, the Sino-Burma border policy adjustments made by China in Dehong are based both on local national security and regional development. Table 1 shows the objective and forms of the border policy.

Table 1. Purpose and implementation methods of the main border policies in Dehong, Yunnan.

\begin{tabular}{lll}
\hline Types of Policy & Purposes of Policy & Implementation Forms \\
\hline & Facilitate contact between borderers & Issue certificates for borderers \\
\cline { 2 - 3 } & Promote border tourism & $\begin{array}{l}\text { Travel permit application from } \\
\text { different locations }\end{array}$ \\
\cline { 2 - 3 } & $\begin{array}{l}\text { Restrict illegal entry-exit (Limits on foreign } \\
\text { workers, illegal immigration, } \text { etc. })\end{array}$ & $\begin{array}{l}\text { National Law on } \\
\text { Entry-Exit Administration }\end{array}$ \\
\cline { 2 - 3 } Entry-exit of personnel & Limit illegal residence within the border & $\begin{array}{l}\text { Temporary residence permit of } \\
\text { borders outside of Yunnan }\end{array}$ \\
\cline { 2 - 3 } & & $\begin{array}{l}\text { Temporary residence permit and } \\
\text { workers' registration certificate } \\
\text { Restrict illegal inbound workers }\end{array}$ \\
\cline { 2 - 3 } & Restrict cross-border gambling border of Yunnan \\
\hline
\end{tabular}


Table 1. Cont.

\begin{tabular}{lll}
\hline Types of Policy & Purposes of Policy & Implementation Forms \\
\cline { 2 - 3 } Cross-border marriages & Limit illegal marriage & Entry-Exit Administration Law \\
\cline { 2 - 3 } & Guarantee de facto marriage & $\begin{array}{l}\text { Inbound marriage registration } \\
\text { certificate }\end{array}$ \\
\cline { 2 - 3 } & Prevent the trafficking of women & $\begin{array}{l}\text { Inbound marriage record registration } \\
\text { certificate }\end{array}$ \\
\hline \multirow{3}{*}{ Border trade } & Promote border trade & $\begin{array}{l}\text { Increase the number of frontier } \\
\text { crossings }\end{array}$ \\
\cline { 2 - 3 } & Prohibit smuggling (drugs and arms) & Customs inspection measures \\
\cline { 2 - 3 } & Adjust the international trade structure & $\begin{array}{l}\text { Adjustment in categories of duty- } \\
\text { free goods }\end{array}$ \\
\hline
\end{tabular}

\section{Policy Effectiveness Analysis}

\subsection{Data Sources}

Our data to measure policy effectiveness comes from in-depth interviews with local government officials and border residents. The main focus of those surveyed includes their understanding of border policies and their degree of satisfaction toward the effects. In August 2013 and April 2014, the research team conducted field surveys on the China-Myanmar border area of Yunnan Dehong Autonomous Prefecture, including Mans, Longchuan, Yingjiang, Ruili City and Wanding City. In-depth interviews were conducted with 72 persons. Table 2 shows the composition of our interviewees.

Table 2. The composition of the interviewees.

\begin{tabular}{cccc}
\hline Items & Categories & Number of Person & Percentage (\%) \\
\hline \multirow{2}{*}{ Gender } & male & 50 & 69.4 \\
& female & 22 & 30.6 \\
\hline \multirow{4}{*}{ Age } & $20-30$ & 23 & 31.9 \\
& $31-40$ & 24 & 33.3 \\
& $41-50$ & 18 & 25.0 \\
& $51-65$ & 7 & 9.8 \\
\hline \multirow{3}{*}{ Ethnic groups } & Tai & 19 & 26.4 \\
& Han & 16 & 22.2 \\
& Jinbo & 29 & 40.3 \\
\multirow{2}{*}{ Occupation } & Burman & 8 & 11.1 \\
& officer & 27 & 37.5 \\
& peasant & 45 & 62.5 \\
\hline \multirow{3}{*}{ Education } & college and above & 13 & 18.0 \\
& high school & 2 & 2.7 \\
& middle school & 22 & 30.6 \\
& primary school & 31 & 43.1 \\
& illiteracy & 4 & 5.6 \\
\hline
\end{tabular}




\subsection{Kaldor-Hicks Analysis Method and Its Application}

The effect of border policies is often manifested in the realization of policy objectives and the degree of realization. However, as mentioned earlier, border policy is sometimes seen a double-edged sword, while bringing benefits, it also has drawbacks. If the benefits outweigh the drawbacks, the policy is considered reasonable. The Kaldor-Hicks method is mainly used to determine the Pareto efficiency $[25,26]$. Pareto efficiency refers to a perfect efficiency and an optimal state. However, most cases in reality operate in a suboptimal state. The state before and after the implementation of a new policy is suboptimal; the Kaldor-Hicks method can be used to compare which is better. The analysis framework is as follows: the gain from the good policies of a particular period $i$ is abbreviated as $G_{i}$, and the loss is abbreviated as $L_{i}$; similarly the policy effects at period $i+1$ are respectively $G_{i+1}$ and $\mathrm{L}_{\mathrm{i}+1}$. If the combined effect of the latter period $\left(\mathrm{G}_{\mathrm{i}+1}+\mathrm{L}_{\mathrm{i}+1}\right)$ is greater than the previous period $\left(\mathrm{G}_{\mathrm{i}}+\mathrm{L}_{\mathrm{i}}\right)$, then the effect of the later period has a Pareto improvement.

We define the gains of border policies as perceived by the local people's level of satisfaction with the policy effects; the loss of the policy compared to the increased net cost for implementing the policy as well as the negative effects of the policy as measured with the dissatisfaction of the locals toward the policy are also considered. To simplify the issue, the cost for the implementation of old and new policies will be taken as a fixed value in the study, because the national expenditure is roughly the necessary cost for implementing these policies. Here we only compare the effects of border policies.

\subsection{Analysis of Interviews with Three Categories of Border Policies}

\subsubsection{Policies on Entry-Exit of Personnel}

Since the majority of interviewees were border residents, we believe that they had the deepest understanding of entry-exit management policies. Common entry-exit activities include: visiting friends and relatives, cross-border trade, seeking medical advice and buying medicine, pilgrimage and prayer, transit grazing, and transit farming. Cross-border entry-exit management mainly includes the confirmation of the border resident' crossing and ports, channels, the scope of activities, the issuance of travel documents, and the inspection and management of border residents. Since 1949, the cross-border migration management policies implemented have had significant positive effects, which have ensured China's security, and basically met the needs of the border residents in terms of production, life and cultural communication. Through interviews, we found that the Chinese border residents themselves agreed that because of the stricter border management policy implemented in China, illegal entry, residence and employment were effectively prevented, and the number of cross-border crimes was reduced. We also found that border residents felt that harsh cross-border policy also has an adverse effect on their life. For example, someone complained that it was difficult for relatives of the other side to come to help during the busy farming seasons due to the complicated policies and formalities. We asked the interviewees to evaluate their gain and lose of the border policies by five levels. Then we got Table 3 . Further, we asked the interviewees to compare the net gain of the border poliy in two stages. We evaluated them with the formulation 1 . The result shows in Table 4.

$$
\left(\mathrm{G}_{\mathrm{i}+1}-\mathrm{L}_{\mathrm{i}+1}\right)-\left(\mathrm{G}_{\mathrm{i}}-\mathrm{L}_{\mathrm{i}}\right)
$$


Table 3. Comprehensive evaluation of the locals on the current border policies.

\begin{tabular}{|c|c|c|c|c|}
\hline $\begin{array}{l}\text { Type of } \\
\text { Policy }\end{array}$ & $\begin{array}{l}\text { Forms of } \\
\text { Implementation }\end{array}$ & $\begin{array}{l}\text { Positive Effect of } \\
\text { the Policy G }\end{array}$ & $\begin{array}{l}\text { Negative Effect of the } \\
\text { Policy L }\end{array}$ & $\begin{array}{l}\text { Combined } \\
\text { Effect } \\
\left(\mathbf{G}_{\mathbf{i}+1-} \mathbf{L}_{\mathbf{i}+}\right) \\
\end{array}$ \\
\hline \multirow{6}{*}{$\begin{array}{l}\text { Personnel } \\
\text { entry and exit }\end{array}$} & $\begin{array}{l}\text { Handle borderer resident } \\
\text { certificate }\end{array}$ & $\begin{array}{l}\text { Convenient for contact } \\
\text { between border residents }\end{array}$ & $\begin{array}{l}\text { A few people feel } \\
\text { concerned }\end{array}$ & Good \\
\hline & $\begin{array}{l}\text { Permission for certificate } \\
\text { application for tourism } \\
\text { in different locations }\end{array}$ & Promote border tourism & No opinion & Good \\
\hline & $\begin{array}{l}\text { State law on entry-exit } \\
\text { administration }\end{array}$ & $\begin{array}{l}\text { Limit illegal entry-exit } \\
\text { (Limit foreign workers, } \\
\text { illegal immigration, etc.) }\end{array}$ & $\begin{array}{l}\text { People who want to go } \\
\text { out to work } \\
\text { feel concerned }\end{array}$ & Good \\
\hline & $\begin{array}{l}\text { Temporary residence } \\
\text { permit of boarder } \\
\text { residents outside Yunnan }\end{array}$ & $\begin{array}{l}\text { Satisfied with limits on } \\
\text { illegal residence within } \\
\text { the border }\end{array}$ & $\begin{array}{l}\text { Individuals and } \\
\text { businesses that employ } \\
\text { foreign workers have } \\
\text { complaints }\end{array}$ & Fine \\
\hline & $\begin{array}{l}\text { Temporary residence } \\
\text { permit of border } \\
\text { residents and registration } \\
\text { certificate for foreign } \\
\text { workers outside Yunnan }\end{array}$ & $\begin{array}{l}\text { Satisfied with orderly } \\
\text { management of foreign } \\
\text { workers }\end{array}$ & $\begin{array}{l}\text { with no adverse } \\
\text { comments }\end{array}$ & Very good \\
\hline & $\begin{array}{l}\text { Agreements on removal } \\
\text { of border gambling } \\
\text { establishments }\end{array}$ & $\begin{array}{l}\text { Satisfaction with the } \\
\text { improvements in social } \\
\text { order }\end{array}$ & No adverse comments & Very good \\
\hline \multirow{3}{*}{$\begin{array}{l}\text { Cross-border } \\
\text { marriages }\end{array}$} & National Marriage Law & $\begin{array}{l}\text { Ensure rights of both } \\
\text { parties of marriage }\end{array}$ & $\begin{array}{l}\text { Cost of certificate is } \\
\text { high }\end{array}$ & General \\
\hline & $\begin{array}{l}\text { Marriage registration } \\
\text { certificate for } \\
\text { border residents }\end{array}$ & $\begin{array}{l}\text { Have a certain } \\
\text { understanding of de facto } \\
\text { marriage }\end{array}$ & No negative comments & Fine \\
\hline & $\begin{array}{l}\text { Marriage record } \\
\text { registration certificate } \\
\text { for border residents }\end{array}$ & $\begin{array}{l}\text { Prevent trafficking } \\
\text { of women }\end{array}$ & No negative comments & Very good \\
\hline \multirow{3}{*}{ Border trade } & $\begin{array}{l}\text { Increase the number } \\
\text { of ports }\end{array}$ & Promote border trade & No adverse comments & Very good \\
\hline & $\begin{array}{l}\text { Customs adopts } \\
\text { measures for prevention }\end{array}$ & $\begin{array}{l}\text { Prevent smuggling } \\
\text { (especially drugs } \\
\text { and arms) }\end{array}$ & No negative comments & Very good \\
\hline & $\begin{array}{l}\text { Adjust the categories of } \\
\text { duty-free goods }\end{array}$ & Good for the nation & $\begin{array}{l}\text { Affected the } \\
\text { local economy }\end{array}$ & Not good \\
\hline
\end{tabular}


Table 4. Evaluation on Pareto improvements in border policy adjustments.

\begin{tabular}{|c|c|c|c|c|}
\hline $\begin{array}{l}\text { Type of } \\
\text { Policy }\end{array}$ & $\begin{array}{l}\text { Changes in the Form of } \\
\text { Implementation }\end{array}$ & $\begin{array}{l}\text { Effect before } \\
\text { Implementation } \\
\mathbf{G}_{\mathbf{i}-} \mathbf{L}_{\mathbf{i}}\end{array}$ & $\begin{array}{l}\text { Effect after } \\
\text { Implementation } \\
\mathbf{G}_{\mathbf{i + 1}-\mathbf{L}_{\mathbf{i}+1}} \\
\end{array}$ & $\begin{array}{l}\text { Improved } \\
\text { or not } \\
\left(\mathbf{G}_{\mathrm{i}+1}-\mathbf{L}_{\mathrm{i}+1}\right)^{-} \\
\left(\mathbf{G}_{\mathrm{i}}-\mathbf{L}_{\mathrm{i}}\right) \\
\end{array}$ \\
\hline \multirow{6}{*}{$\begin{array}{l}\text { Personnel } \\
\text { entry-exit }\end{array}$} & $\begin{array}{l}\text { In 2013, simple formalities in } \\
\text { handling border resident permit }\end{array}$ & Fine & Good & Improved \\
\hline & $\begin{array}{l}\text { In } 2013 \text {, restoration of handling travel } \\
\text { permit from different locations }\end{array}$ & Not good & Very good & Improved \\
\hline & $\begin{array}{l}\text { In } 2012 \text {, revision of national } \\
\text { entry-exit law }\end{array}$ & Fine & good & Improved \\
\hline & $\begin{array}{l}\text { In } 2011 \text {, issuance of temporary } \\
\text { residence permits for residents outside } \\
\text { of the border of Yunnan }\end{array}$ & Fine & Fine & Improved \\
\hline & $\begin{array}{l}\text { In 2011, issuance of temporary } \\
\text { residence permit and registration } \\
\text { certificate of foreign workers } \\
\text { in Yunnan }\end{array}$ & Fine & Fine & Improved \\
\hline & $\begin{array}{l}\text { In } 2009 \text {, removal of border gambling } \\
\text { establishments }\end{array}$ & Not good & Very good & Improved \\
\hline \multirow{2}{*}{$\begin{array}{l}\text { Cross-border } \\
\text { marriages }\end{array}$} & $\begin{array}{l}\text { In 2001, amendment on the National } \\
\text { Marriage Law }\end{array}$ & General & General & $\begin{array}{l}\text { Without significant } \\
\text { improvement }\end{array}$ \\
\hline & $\begin{array}{l}\text { In } 2010, \text { marriage registration } \\
\text { certificate of boarder residents }\end{array}$ & Not good & Fine & Improved \\
\hline \multirow{4}{*}{ Border trade } & $\begin{array}{l}\text { In 1992, Wanding port of Dehong was } \\
\text { approved as an open city }\end{array}$ & Fine & Very good & Improved \\
\hline & $\begin{array}{l}\text { In 1982, anti-drug work leading group } \\
\text { was established in Yunnan province. } \\
\text { In 1990, National Narcotics Control } \\
\text { Commission was established }\end{array}$ & Fine & Fine & $\begin{array}{l}\text { Without obvious } \\
\text { improvements }\end{array}$ \\
\hline & $\begin{array}{l}\text { In 2003, the General Administration } \\
\text { of Customs issued the "list of goods } \\
\text { on which imported tax policy are for } \\
\text { implemented in border trade"; } \\
\text { in 2010, the General Administration of } \\
\text { Customs abolished this list. }\end{array}$ & Fine & Not good & Unimproved \\
\hline & $\begin{array}{l}\text { In 1996, Kunming Customs and State } \\
\text { Administration of Taxation of Yunnan } \\
\text { issued "interim measures for import } \\
\text { tax administration in border trade } \\
\text { of Yunnan" }\end{array}$ & Good & Fine & Improved \\
\hline
\end{tabular}

\subsubsection{Cross-Border Marriages Policy}

According to the survey, 9412 Myanmar nationals registered for marriage in Dehong, and 9485 children were born. The border policy can effectively implemented to limit the illegal cross-border marriages 
and maintain stable ethnic relations on both border sides. The previous cross-border marriages policy was quite flexible and liberal, and Burmese brides would be recognized for their citizenship for they get a certificate for marriage from the local departments, and they could enjoy preferential policies on the Chinese border region. According to our survey (see Table 5), except for two villages near the town, other villages have a high proportion of cross-border marriages. In addition, because of crossborder marriages, social management is increased, especially family planning.

Table 5. Statistics of cross-border marriages of Zhangfeng port in Yunnan (2014).

\begin{tabular}{ccccc}
\hline Name of Village & $\begin{array}{c}\text { Number of } \\
\text { Families }\end{array}$ & $\begin{array}{c}\text { Number of } \\
\text { Foreign Families }\end{array}$ & $\begin{array}{c}\text { Proportion of Foreign } \\
\text { Families (\%) }\end{array}$ & $\begin{array}{c}\text { Number of Children of } \\
\text { Foreign Families }\end{array}$ \\
\hline Zhangfeng village & 1138 & 57 & $5.01 \%$ & 25 \\
Hunong village & 1268 & 179 & $14.12 \%$ & 90 \\
Mengla village & 1065 & 152 & $14.27 \%$ & 102 \\
Diesa village & 864 & 97 & $11.23 \%$ & 48 \\
Mangnong village & 908 & 78 & $8.59 \%$ & 30 \\
Nongguan village & 1148 & 51 & $4.44 \%$ & 25 \\
Lameng village & 1522 & 176 & $11.56 \%$ & 45 \\
Xincheng & 2740 & 7 & $0.26 \%$ & 4 \\
Laojie & 2393 & 23 & $0.96 \%$ & 437 \\
Total & 11928 & 820 & $6.87 \%$ & \\
\hline
\end{tabular}

Source: The family planning office of Longchuan County in Dehong Prefecture [27].

\subsubsection{Border Trade Policy}

The border trade volume of Dehong prefecture is closely related to the tax-free policy of the national border. Some scholars believe that local trade will be flourishing due to preferential policies. However, without preferential policies, the border trade would decline immediately. The Chinese government has stipulated duty-free policies on 162 different kinds of products imported from Myanmar. It confirmed that these policies were conducive to maintaining the bilateral trade pattern that we exchange resource products from Myanmar with middle and low level industrial products. Overall, the border trade policies have effectively promoted cross-border trade and the economic development of Dehong. For example, the total value of imports and exports has steadily risen since the Zhangfeng gateway was approved in 1991. However, there were small fluctuations (see Table 6). These fluctuations were not entirely caused by tax policy changes. The border trade policy was determined by a complex economic system. It was hard to judge whether the current barriers such as tariff rates, import and export quotas and licenses are beneficial or not; the only way to improve is to improve the gateway infrastructure in the future. While the cross-border trade has little effect on regional economy, but it would increase the living conditions of the residents' daily lives. 
Table 6. Statistics of Zhangfeng port in Yunnan.

\begin{tabular}{ccccc}
\hline Year & $\begin{array}{c}\text { Total Value of Imports and } \\
\text { Exports (RMB Million) }\end{array}$ & $\begin{array}{c}\text { Total Imports and } \\
\text { Exports (Tons) }\end{array}$ & $\begin{array}{c}\text { Number of } \\
\text { Entry-Exit Personnel }\end{array}$ & No. of Vehicles \\
\hline 1996 & 5000.00 & $17,000.00$ & 14,900 & 6900 \\
1997 & 5095.36 & $18,178.07$ & 15,476 & 7919 \\
1998 & 5025.09 & $31,573.49$ & 20,384 & 4650 \\
1999 & $20,013.76$ & $32,702.47$ & 97,824 & 12,274 \\
2000 & $22,967.00$ & $43,994.00$ & 93,588 & 14,046 \\
2001 & $14,287.32$ & $18,703.34$ & 136,146 & 12,272 \\
2002 & $23,657.75$ & $27,612.42$ & 268,007 & 43,822 \\
2003 & $37,100.58$ & $62,532.72$ & 362,708 & 35,793 \\
2004 & $27,420.27$ & $32,485.07$ & 514,318 & 324,557 \\
2005 & $24,130.08$ & $36,489.28$ & 508,766 & 33,718 \\
2006 & $29,036.60$ & $36,755.00$ & 570,991 & 55,525 \\
2007 & $47,321.00$ & $59,052.00$ & 585,312 & 36,854 \\
2008 & $69,572.34$ & $98,425.52$ & 571,161 & 40,801 \\
2009 & $90,988.53$ & $109,319.81$ & 492,316 & 28,481 \\
2010 & $157,905.37$ & $173,595.51$ & 595,352 & 51,609 \\
2011 & $96,807.33$ & $199,042.04$ & 680,770 & 98,768 \\
2012 & $134,153.35$ & $180,932.47$ & 930,975 & 258,861 \\
2013 & $140,462.12$ & $241,042.00$ & $1,184,818$ & 373,852 \\
\hline
\end{tabular}

Source: Department of Commerce of Yunnan [28].

\section{Discussion}

To sum up, this study is one of the first studies that has examined specifically the effectiveness of Chinese border policies on a border region. This study has some limitations which can be overcome with the future research. First, the number of interviewees is relatively small, so the results about satisfaction towards policy effects may not represent the entire population in Dehong Prefecture, and the country; Second, we assume that the additional cost of government policy adjustment is zero, which most likely is not fully in line with reality; Third, many data involving state policies are not readily available for this study, for example, data on smuggling, drug trafficking, and espionage. Therefore, the entire effects of border policy cannot be known. We hope additional data will be provided for the future studies.

According to this study, the Kaldor-Hicks analysis method can be used as a universal method for evaluation of border policies. The questions might be asked: Is there a better evaluation method for different regions? Or is there an evaluation method that combines the common interest between countries on either sides of the border, or the national interests and local interests? These questions require further research by more scholars.

\section{Conclusions}

Based on a large number of geographical studies about borders and border regions, we reviewed the evolution of border management policies in Dehong Dai and Jingpo Autonomous Prefecture. We sought to establish a theoretical framework for evaluating China's border management policies. After 
obtaining relevant materials and analyzing the statistics results of interviews, we explored evaluation methods and decided to use the Kaldor-Hicks method. This paper has two important conclusions:

Firstly, the Kaldor-Hicks method can be seen as an effective method to evaluate the effectiveness of China's border policies. This method has two advantages: First, it provides a relatively complete descriptive evaluation, which is a small step forward. Second, it can be used to compare the two policies. Secondly, we can observe the overall effects of adjustments in border policies in Dehong Prefecture. However, sometimes the border trade policies are good for the country as a whole, but not necessarily beneficial for these in Dehong Prefecture. For the sake of the whole country, these adjustments in border trade policies need to be compensated by financial transfers. In addition, the combined effects of the cross-border marriages policies are not obvious. In addition, much more work on this topic is needed.

\section{Acknowledgments}

This research is supported by National Key Technology R\&D Program (2012BAK12B03), and the Natural Science Foundation of China (41171097). All the authors gratefully thank the interviewees for participating in the research, and also the reviewers and editor. We also acknowledge the help provided by Jun Chen, Yapin Chen, Jianhua Bu, Shaobo Zhang, Yan Tian, Hao Hu,and Shufang Wang in School of Geography Beijing Normal University for their constructive suggestions for this paper. Thanks also to Stanley Brunn's language polishing and editing.

\section{Author Contributions}

Qianlong Bie played an important role in the conception of the study, performing the data analyses, drafting and revising the manuscript. Cansong Li contributed to the data gathered and played an important role in interpreting of the results. Shangyi Zhou contributed to the conceptual framework of the methodology and analysis of Tables 3 and 4.

\section{Conflicts of Interest}

The authors declare no conflict of interest.

\section{References}

1. Paasi, A. A geographical perspectives on Finnish national identity. GeoJournal 1996, 43, 41-50.

2. Newman, D.; Paasi, A. Fences and neighbors in the postmodern world: Boundary narratives in political geography. Prog. Hum. Geogr. 1998, 22, 186-207.

3. Yang, C. Multilevel governmence in the cross-boundary region of Hong Kong-Pearal River Delta, China. Environ. Plan. A 2005, 37, 2147-2168.

4. Freeman, C.; Thompson, D. China on the Edge: China's Border Provinces and Chinese Security Policy; Manas Publications: New Dehli, India, 2014.

5. Newman, D. The lines that continue to separate us in our borderless world. Prog. Hum. Geogr. 2006, 30, 143-161. 
6. Rumley, D.; Minghi, J.V. The Geography of Border Landscapes; Routledge: London, UK; New York, NY, USA, 1991; pp. 280-309.

7. Boedeker, J. Cross-border trade and identity in the Afghan-Iranian border region. In Subverting Borders: Doing Research on Smuggling and Small-Scale Trade, 1st ed.; Bruns, B., Miggelbrink, J., Eds.; Deutsche Nationalbliothek: Leipzig, Germany, 2012; pp. 35-54.

8. Harris, T. Trading places: New economic geographies across Himalayan borderlands. Polit. Geogr. 2013, 35, 60-68.

9. Van Houtum, H. An overview of european geographical research on borders and border regions. J. Broadlands Stud. 2000, 1, 47-56.

10. Van Houtum, H. The geopolitics of borders and boundaries. Geopolitics 2005, 10, 672-679.

11. Cons, J.; Sanyal, R. Geographies at the margins: Borders in South Asia. Polit. Geogr. 2013, 35, 5-13.

12. Van Houtum, H.; van Naerssen, T. Bordering, ordering and othering. Tijdschr. Econ. Soc. Geogr. 2002, 93, 125-136.

13. Houtum, H.; van Gielis, R. Elastic migration: The case of dutch short-distance transmigrants in belgium and german borderlands. TESG 2006, 2, 195-202.

14. Willis, H.H.; Predd, J.B.; Davis, P.K.; Brown, W.P. Measuring the Effectiveness of Border Security between Ports-of-Entry. In Homeland Security and Defense Center Report; RAND Corporation: Santa Monica, CA, USA, 2010.

15. Minghi, J. Boundary studies in political geography. Ann. Assoc. Am. Geogr. 1963, 53, 407-420.

16. Rosenblum, M.R.; Bjelopera, J.P.; Finklea, K.M. Border Security: Understanding Threats at U.S. Borders; Congressional Research Service: Washington, DC, USA, 2013.

17. Czaika, M.; de Haas, H. The Effectiveness of Immigration Policies: A Conceptual Review of Empirical Evidence; International Migration Institute: Oxford, UK, 2011; pp. 1-26.

18. Hansen, N. Border regions: A critique of spatial theory and A European case study. Ann. Reg. Sci. 1977, 11, 1-14.

19. Stiller, A.N.S. Integration Effects in Border Regions: A Survey of Economic Theory and Empirical Studies; Hamburg Institute of International Economics: Hamburg, Germany, 2001; pp. 406-417.

20. O'Dowd, L. From a "borderless world" to a world of borders: "Bringing history back in". Environ. Plan. D Soc. Space. 2010, 28, 1031-1050.

21. Jones, R. Geopolitical boundary narratives, the global war on terror and border fencing in India. Trans. Inst. Br. Geogr. 2009, 34, 290-304.

22. Lu, G. A study of the transnational floating population in the Sino-Burmese border areas. J. Yunnan Natl. Univ. 2006, 16, 5-10.

23. Wang, S. Sino-Myanmar's border trade, industry linkage and border trade products processing. J. Southwest Univ. Natl. 2007, 3, 198-202.

24. Li, J. The restrictive factors and countermeasures for the development of bilateral trade between China and Myanmar. People's Trib. 2013, 7, 238-240.

25. Stringham, E. Kaldor-Hicks Efficiency and the problem of central planning. Q. J. Austrian Econ. 2001, 4, 41-50. 
26. Farrow, S. Environmental equity and sustainability: Rejecting the Kaldor-Hicks criteria. Ecol. Econ. 1998, 27, 183-188.

27. The family planning office of Longchuan County in Dehong Prefecture. Available online: http://www.dhlc.gov.cn/ (accessed on 20 April 2014).

28. The Department of Commerce of Yunnan. Available online: http://yunnan.mofcom.gov.cn/ (accessed on 20 August 2013).

(C) 2014 by the authors; licensee MDPI, Basel, Switzerland. This article is an open access article distributed under the terms and conditions of the Creative Commons Attribution license (http://creativecommons.org/licenses/by/3.0/). 